This is the peer reviewed version of the following article: Galloway, S. (2012), Reconsidering Emancipatory Education: Staging a Conversation Between Paulo Freire and Jacques Rancière. Educational Theory, 62: 163-184. doi: 10.1111/j.1741-5446.2012.00441.x, which has been published in final form at http://onlinelibrary.wiley.com/doi/10.1111/j.1741-5446.2012.00441.x/full. This article may be used for non-commercial purposes in accordance With Wiley Terms and Conditions for selfarchiving. 


\section{Reconsidering emancipatory education: Staging a conversation between Paulo Freire and Jacques Rancière}

\section{Abstract}

This essay considers emancipation as a purpose for education through considering the theories of Paulo Freire and Jacques Rancière. Both theorists are concerned with the prospect of distinguishing between education that might socialise people into what is taken to be an inherently oppressive society and education with emancipation as a purpose. Galloway reconstructs the theories in parallel examining the assumptions made, the processes of oppression and the movements to emancipation. In so doing she argues that that the two theorists hold a common model for theorising oppression and emancipation as educational processes, distinguished by the differing assumptions they each make about humanity, but with opposing implications for educational practices. Also, that Freire and Rancière raise similar educational problems and concerns, both theorising that the character of the relationships between teachers, students and educational materials is crucial to an emancipatory education. Galloway's approach allows discussion of some of the criticisms that have been raised historically about Freire's theory and how these might be addressed to some degree by Rancière. Taking the two theories together, she argues that the possibility of an emancipatory education cannot be ignored if education is to be considered as more than the passing down of skills and knowledge necessary to socialising people into current society.

\section{Introduction}

This essay considers the work of two theorists who have explored the possibility of emancipation as a purpose for education; Paulo Freire and Jacques Rancière. Both theorists are concerned with the prospect of distinguishing between education that might socialise people into what is taken to be an inherently oppressive society and education with emancipation as a purpose. Here Freire describes oppression as the societal enactment of 'banking education' and develops an emancipatory 'problem posing' education in the form of conscientization projects linked to the possibility of social transformation. By contrast, Rancière 
describes oppression as a pedagogization of the social order referred to as an intellectual 'stultification', where emancipation is a movement towards individual intellectual freedom.

Freire and Rancière both outline their theories of emancipatory education in a single short volume of text. In the case of Freire, Pedagogy of the Oppressed ${ }^{l}$ comprises the bulk of his theoretical work and forms the basis of this essay; concise but varied, it encapsulates the theory and ideas that inform much of his later writing concerned with educational practices and judgements ${ }^{2}$. Though first published in English in 1970, Pedagogy of the Oppressed still maintains influence after forty years, particularly amongst practitioners in the field of adult education. Though Rancière's The Ignorant Schoolmaster ${ }^{3}$ has been in print since 1991, interest in the contribution it might make to education is much more recent ${ }^{4}$. Here attention has been given to Rancière's description of emancipatory education, which, according to Biesta $^{5}$, challenges the model that is commonly advocated by critical educators. This challenged model is one where the aim of education is to expose the workings of power because explaining how the world really is leads to emancipation. Biesta argues that this is in keeping with a strand in the critical tradition where emancipation is understood to be brought about from the outside and where the task of critical social science is to make visible that which is hidden from everyday view, the problem being that this creates a dependency between emancipators and emancipated.

In this essay I argue that both Freire and Rancière challenge this conception of critical education and, what's more, that both theorists are concerned with similar questions though their respective approaches raise contrasting problems and issues with oppositional implications for educational practices. This isn't just an interesting aside. The discussion between the two theories that I present here brings to the foreground the question of the possibility of an emancipatory education and stimulates an important and as yet unresolved conversation which in its broadest terms questions the purpose of education itself ${ }^{6}$. 
Through reconstructing the two theories I will argue that each is concerned centrally with how to distinguish between education that socialises people into what is considered to be an intrinsically oppressive society and education with the purpose of creating possibilities for opposition to or freedom from society as it stands ${ }^{7}$. Both Freire and Rancière argue that education isn't neutral and by default is oppressive, but also that education can encourage possibilities for emancipation. Crucially, they both describe how education for emancipation is not reliant upon teachers delivering more correct knowledge to students about the nature of their oppression, arguing instead that such educational practices actually replicate societal oppression. Rather, importance is placed upon the character of the relationships between students and teachers and the relationship between these people and the educational materials that they use (though in the case of Freire, the content of such materials is also significant). For both, emancipatory education cannot be systemised or implemented by government policy, demanding instead that people trust one other. Though they offer different conceptualisations of emancipation, both Freire and Rancière describe its pursuit as a risky undertaking which people try to avoid, encouraging a tendency for people to replicate oppression themselves.

I will also describe how the differing assumptions that underpin the two theories point towards educational practices that might raise the possibility for emancipation. Each theory implies that an emancipatory education requires particular kinds of relationships between students and teachers as well as specific purposes for the use of educational materials. But these implied practices are not the same, with the educational activity suggested by Freire contradicting that suggested by Rancière. So, whilst both theories argue strongly for the possibility of an emancipatory education, there is no single conclusion as to what an emancipatory education might consist of in practice.

Paulo Freire and Jacques Rancière both describe oppression and emancipation as educational endeavours. To do this they each present assumptions about humanity and use these to produce a definition of equality. 
This then allows oppression to be described in terms of educational activity that would deny or undermine equality, with the corollary that emancipation might result from educational alternatives that re-instigate it. To demonstrate this shared model of theorising about emancipation, in this essay I reconstruct the theories in parallel and in three stages examining the assumptions made, the processes of oppression and the movements to emancipation. Taking the two theories together in this way allows me to consider how the assumptions that we make about people might influence how we understand and practice education. It also allows me to demonstrate some of the criticisms that have been raised historically about Freire's theory and how these might be addressed to some degree by Rancière. However, I also question the necessity for theories of emancipatory education to follow the model of theorising that Freire and Rancière demonstrate. Here I argue that the discussion must continue if educators are to take responsibility for the purpose of education and if education itself is to be understood as something more than the teaching of the skills and knowledge required for participation in society as it stands.

\section{Assumptions: Innate characteristics or everyday opinions}

Both Freire and Rancière set out assumptions which are used firstly to define equality and then to describe oppression and emancipation also. Freire asserts that all people are conscious beings who are equally predisposed to reflect and act upon the world around them. Such social activity is assumed to be integral to the innate character of humanity and if it is suppressed or prevented then social inequality results. Rancière's definition of equality is described in terms of the opinion that all people are equally capable of directing their intellect towards forming their own opinions. This means that if the intellectual activity that is necessary to forming opinions is suppressed or undermined, then inequality is replicated in society. Each theorist elaborates a complicated theory of emancipatory education from these brief definitions of equality, which this essay sets out to reconstruct.

Freire assumes that people are conscious beings that have evolved from and are part of an ever changing natural world. Humans inhabit an intersubjective 'world' where they are aware of themselves and each 
other as well as external reality (PO, 54-55) within the context of ceaseless change. As historical beings, people are aware of a past, present and future which allows them to separate themselves from the consequences of their actions encouraging them to believe that reality can be transformed through conscious activity. There is no need for people to resign themselves to the physical and social world as it is because they can make conscious plans to take action that might change it. This drive for transformation and inquiry informs Freire's conceptualisation of education as the enactment of humanity's conscious and eternal striving towards completeness in the context of an ever changing social and physical world (PO, 56-57).

Freire draws upon a Marxian notion of praxis which is presented as integral to humanity's innate way of being, (PO, 70, 96), described as a social relationship between people and the social and physical world, where they simultaneously and consciously reflect and act upon that world. Praxis must involve both action and reflection; a dialectical relationship where action should lead to critical reflection and where this reflection if 'true', will lead to action (PO, 27-8, 40-41, 96). For Freire, the reflection that is integral to praxis is reliant upon dialogue between human subjects whilst they consider the concrete situations that affect them. Here Martin Buber's dialogical humanism informs Freire's notion that dialogue might offer release from dominating relationships, transforming subject - object relationships between people into relationships of co-subjects $(\mathrm{PO}, 135)$. This allows Freire to open the possibility for emancipatory relationships between people, where love, trust and hope are integral to praxis.

Freire elaborates on the nature of humans as transformative and reflective actors drawing upon Marx's early writings on alienation (The 1844 Manuscripts) and those of Alvaro Vieira Pinto on the relationship between humans and the physical and social situations that limit their possibilities to act, which are described as 'limit-situations'. In an oppressive society 'limit-situations' may be the consequence of domination and once they are perceived, humans can respond to the challenges they pose by planning and 
acting against them with 'limit acts', for there is no need to accept the world as it is. (PO, 70-1). The possibility of dealing with limit-situations is the driver behind people's ability to have hope and confidence for the future. The ensuing transformation of situations and circumstances creates new situations and new limitations, in turn invoking new limit-acts.

The transformative actions of humanity as a never ending praxis represents people's permanent educational engagement with the physical and social world, driven by the limit situations they perceive around them. Freire conceptualises emancipatory education as educational activity that encourages and sustains praxis. This demarcates Freire from a prevalent tradition in Western society, associated with the Enlightenment, where the purpose of education is to create rational and autonomous individuals who can think and act independently ${ }^{8}$. Significantly, the emphasis Freire places on dialogue in the context of praxis describes an education that is inherently social and that might orientate towards wider goals of social justice. For Freire, the social character of emancipatory education makes individual emancipation as impossible as being the midwife at one's own birth (PO, 25) $)^{9}$.

Freire defines oppression as a process of dehumanisation that occurs when people's natural ways of being in praxis are disrupted or suppressed. The concept of praxis that Freire describes might suggest human subjects in constant flux, immersed in ever changing relationships with the social and physical environment. However, praxis as a description of the innate character of humanity is itself a static notion, which in turn fixes Freire's definition of oppression. This makes the definition of oppression totally reliant on the adequacy of the assumptions already made about the character of humanity and Freire's theory has been criticised specifically on this point, for example through arguments that the theory doesn't fully encompass gender ${ }^{10}$. Such criticisms represent a wider concern that theories of education based upon assumptions about human nature are both impossible and undesirable, with potentially dangerous consequences $^{11}$. 
Rancière draws our attention to questions about truth and knowledge through a wide body of theory concerned with emancipation that does not rely upon truth assumptions about the nature of people ${ }^{12}$. In $T h e$ Ignorant Schoolmaster the discussion is informed by 'opinions', taking the description of oppression and the movement to educational emancipation in a different direction. In Rancière's writing opinions are not presented as an account of the innate character of human beings or even as being consequent of organised empirical research. Opinions are just opinions. But the opinions that Rancière raises inform understandings about how opinions arise in the first place as well as conceptualisations of both equality and oppression. So the use of opinions is in keeping with the arguments that the theory makes to describe possibilities for an emancipatory education.

Rancière has produced a body of work which explores emancipation as the enactment of the supposition of equality between all people ${ }^{13}$. In keeping with this, the Ignorant Schoolmaster explores this notion of emancipation in the context of education commencing with the opinion that all people have equal intelligence and Rancière's writing can be read as an example of what can be achieved under this supposition of equality. It is elaborated through the story of an educator, a teacher named Joseph Jacotot. Jacotot discovers emancipatory education by accident from observations made when he was teaching a language he didn't know. He gave the students a bilingual text and left them to figure it all out for themselves, which they did, setting the scene for the Ignorant Schoolmaster.

Rancière observes that people will achieve different outcomes and degrees of success when they work on an identical task, suggesting that all people are not equal. If people are equal in their intelligence, how does this account for evidence that suggests the contrary? As a consequence of anecdotal observations a second opinion is introduced that 'man is a will served by an intelligence'14 (IS, 51 - 52). The performance of intelligence, or equality, relies on an act of the will. Those who don't attend to their will 
are enacting a form of intellectual weakening, creating diversity in achievement in specific situations. Equality between people is reliant upon individuals attending to their will whilst acting under the assumption that everyone has equal intelligence. If people rely on the intellect of others, accepting others' opinions and neglecting to form their own, they fail to attend to their own will and equality is no longer enacted. The consequence of this argument is that reliance on a group will undermines equality, making all societal institutions enactors of inequality and inherently oppressive. From here, Jacotot's initial opinions produce a third opinion that: 'it is precisely because each man is free that a union of men is not' $(I S, 78)$.

So far I have described the assumptions Freire and Rancière make in their respective theorising of oppressive and emancipatory education. For Freire, the assumptions encompass a description of the innate character of humanity where people are taken to be conscious and historical beings living in praxis. In contrast, in The Ignorant Schoolmaster, Rancière's avoids the making of truth assumptions about humans, where the theory is constructed as an enactment of the opinion that all intelligences are equal. I shall now describe the educational processes of oppression that each theory constructs on the basis of these assumptions.

\section{Processes of oppression: banking education or stultification}

In this section I will describe how both theorists describe oppression as an educational process of knowledge transmission that is enacted and replicated throughout society and its institutions, not just in schools or colleges. Also, how for both, oppression is understood as the dichotomising of the human attributes that are necessary to equality. In Freire's case, oppression is the dichotomising of people from the world; the separation of reflection from action. This is the breaking down of humanity's innate ways of being in praxis and results from human activity that blocks dialogue between people. Rancière describes oppression as a dichotomy of intelligence dividing people into a world of ignorant minds and knowing 
minds that is enacted through the educational process of explication (ie explanation). Both theorists describe oppression as an educational process which is enacted and replicated throughout society.

Freire refers to Hegel to describe a class driven oppression where dehumanisation is a fundamental attribute of society (PO, 21-22). Oppressor and oppressed classes are locked into a co-dependent struggle for recognition which will only be resolved when the dehumanisers are defeated. But it isn't people's destiny to be oppressed; rather it is their vocation to become human and this struggle can only be led by the oppressed who will free their oppressors as well as themselves. Oppressors make oppressed people dependent upon them for knowledge about the world, but they themselves are dependent upon the oppressed for the possibility of a future social emancipation. Here Freire makes clear that this project need not be left to chance for there can be a role for humanising education.

The separation of humanity from the physical and social world is enacted by an oppressor class that acts as though other people are mere objects rather than fellow humans. They render everyone inanimate in an all encompassing act of dehumanisation which, drawing on Fromm, Freire equates directly to sadism, violence and a love of death (PO, 40, 50-51). For the oppressors, 'to be is to have and to be of the 'having' class' (PO, 35) and so they live in a world without people. The oppressed, objects in the world of the oppressors, are people without the world. They are encouraged into passivity, disconnected from active engagement with the world because 'as things they have no purpose except those that the oppressors prescribe for them' $(\mathrm{PO}, 36)$.

For Freire, dialogue is integral to praxis to the extent that oppression is physically enacted through 'antidialogical acts' that isolate people by interrupting the social reflection that must accompany all action. Anti-dialogical acts take the form of mythmaking, sloganeering, and cultural invasion which distrusts people and serves to keep them apart. This is enacted throughout society, including organisation aimed at reducing inequality such as the welfare system, development projects and political parties. Freire describes 
this replication of oppression as an educational process called banking education.

The banking education model describes a social world where oppressors, as teachers, assume the role of subject and act to make people (as students) objects by regulating and controlling the knowledge of the world that enters their consciousness. Students may not open their consciousnesses to the world as they intend, but passively receive it in the form of deposits which they may file and store. The teacher teaches, knows, thinks, talks, chooses, acts and decides. But students, as the objects of education, do the opposite of all of these things, making them dependent on the teacher for these actions. They are receptacles for knowledge about the world that they may collect, catalogue and store but not act upon, transform or recreate. The teacher justifies this relationship by presenting themselves as knowledgeable, encouraging students to accept themselves as ignorant (PO, 46-49).

Banking education controls people's conscious engagement with the world, making them receptive to knowledge transmission from the 'teacher' and less able to communicate or reflect amongst themselves. This socialises the banking educated person into a world of objects; the oppressive society created by the oppressor class. They accept the status quo and believe that they cannot engage with the world other than through the teacher's guidance. This false perception prevents them from objectifying the oppressor; indeed, they may admire oppressive people and harbour ambitions to be like them, as the peasant dreams of becoming a landowner. As banking education denies the ever changing nature of people and the world they inhabit, oppression seems to be permanent with no prospect or possibility for change. Though they know that they are oppressed, perception of their situation is impaired such that they may be unable to describe the reality of their own oppression. This controversial notion gives Freire's theory the difficult job of describing an emancipatory education that can overcome the false consciousness of 'the oppressed' without resorting to educational liberators revealing the true world to 'them' in an endeavour to emancipate from the outside, for this would only serve to continue banking education. For me, this is the task that 
Freire attempts, the question being how successful the theory is in dealing with the problem.

Rancière doesn't rely on notions of humanity as conscious beings and so offers a departure from the concept of a false consciousness ${ }^{15}$. In common with Freire, Rancière sets up an educational model for the enactment of oppression in society which all social institutions replicate, not just schools or colleges, but takes schooling as a detailed example ${ }^{16}$. Here, school children are encouraged to believe that they can't understand without explanation (ie explication) which makes them intellectually reliant on a teacher, in contradiction to life before school when children learn to speak, relate and do with no explanation. This makes school a place where children grieve over the loss of their ability. The continual process of explication may be the result of a teacher's good intentions but also serves the purpose of allowing the teacher to reinforce their status as the knowledgeable one. The more the teacher explains, the more the child becomes dependent on explanation; it is a regression ad infinitum. The teacher may be well meaning and conscientious, perhaps even arguing that 'teaching was not about cramming students with knowledge and having them repeat it like parrots' (IS, 3). But unlike Freire who views such techniques as aspects of a banking education, cramming isn't the problem. The problem is explanation, which assumes that children need help to understand.

For Rancière, the word understanding 'throws a veil over everything' (IS, 6). The teacher obscures knowledge and then gradually unveils it making teaching the art of continually gauging the distance between the taught material and the understanding of student. Using Freire's description of banking education this process could be interpreted as the regulation and control of the knowledge that enters into a student's consciousness; an oppressive act of objectification. But Rancière makes no assumptions about human consciousness, constructing inequality as the oppressive educational process of explication which enforces the notion that the student has an inferior intelligence, encouraging the belief that some are more intelligent than others. The result isn't 'false consciousness', but rather a kind of intellectual laziness 
underwritten by the belief that all people vary in intellect (IS, 40). This weakens the attention people give to their own intellectual powers, replicating inequality.

Whilst Freire characterises the enactment of oppression as the dichotomising of subject from object, people from the world, where the oppressed are made objects in a world without people, Rancière is describing the dichotomy of intelligence into 'a world divided into knowing minds and ignorant ones, ripe minds and immature ones, the capable and the incapable, the intelligent and the stupid' (IS, 6). Explication is enacted and replicated in society as a whole, in what Rancière describes as a series of interlocking circles of inequality. For example, in relation to child development, professionals might perform tests on children' brains supposedly producing evidence of the difference in their intellectual capability (IS, 47), under the premise that it is natural for intelligences not to be equal. This supposed measurement of intelligence is actually an enactment of inequality because people can't (and in point of fact haven't) measured differences in intelligence., All they are doing is explaining differences by giving them the meaningless label of intelligence and using this to reinforce a circle of inequality where the oppressive opinion that all people are unequal is re-stated endlessly.

This process of reinforcing inequality through explication prevails throughout society including parliament, government, academia and courts of law. A stultifying educational process is also enforced by those who aim to help the common people, including those (like Freire) with a goal to undermine the social order. Revolutionaries, progressives, supporters of meritocracy and philanthropic rulers are bundled together by Rancière as people of good intention but with something else in common too. They all transmit their ideas via an explicatory monitor system; an inverted tree of instruction from which their orders radiate outwards. Their intention is to explain knowledge to people, be it political science, psychology, sociology or journalism, believing that they are encouraging the possibility of liberty when actually they are extending the reach of inequality (IS, 17).Of course more inequality means even more explanatory 
work for the revolutionaries and progressives to attend to! And so the cycle of inequality continues...

Rancière presents a very strong statement against the possibility for social science to contribute to the preservation of humanity. If humans are studied and explained like other animals under the auspices of natural science then their continuance as a species need not be considered because the natural laws cannot raise such questions. The needs of existence can only be attended to by individuals using their will to guide their intelligence and so creating their own opinions. Rancière describes how social science utilises the intellect of ordinary people whilst simultaneously functioning to suppress it. Systemised social science instruction enacts oppression by taking opinions that might originate with the every day habits of ordinary people and then explicating these back to them as though they cannot understand them, telling people that:

'An opinion is a feeling we form about facts that are superficially observed. They are from weak and common minds and are the opposite of science which knows the true reasons for phenomena' (IS, 45)

Such explanations and explanatory theories not only encourage the oppressive opinion that people have unequal intelligence, they also undermine the attention people might give to their intellectual powers, weakening the intellectual activity from which opinions originate in the first place, for 'where need ceases, intelligence slumbers' (IS, 51). Here Rancière is clearly demarcated from Freire; oppressed people don’t have a false consciousness and are not disconnected from the world, rather there is a weakening of the will; an intellectual laziness encouraged by the belief that some are more intelligent than others. The understandings of oppression and emancipation that Freire and Rancière describe have implications for the character of emancipatory education, which is discussed in the next part of this essay.

\section{Freire's emancipatory education}

In keeping with the notion of praxis, Freire presents emancipatory education as a practice as well as a 
theory, describing how an educational project might be conducted 'on the ground'. Emancipation must not involve the practice of educators explaining more correct knowledge of people's objective situation back to them as liberators coming from the outside because this replicates banking education. Here Freire develops Lukac's notion of critical intervention as the unveiling of objective reality to 'the masses' so that it departs from this model. Instead of knowledge transmission, it is the relationship between educator, students and the 'world' that is of importance. The role of the teacher is to re-instigate dialogical and reflective practices which in turn re-initiate praxis and link people back to the world (PO, 30). It is dialogue within the educational relationship that drives the emancipatory process, whilst 'the world' holds a mediating role (PO, 53). This raises questions about the status of dialogue and 'the world' in the educational emancipatory process.

For Freire, dialogue is essential to the dialectic between reflection and action that constitutes praxis. This makes dialogue the driver of the trajectory to emancipation, but Freire introduces another dimension. A profound love for the world and for humanity is described as prerequisite to dialogue. Martin Buber informs Freire's notion that those in dialogue may depart from relationships of domination opening up not just the possibility, but the necessity for a non-oppressive relationship between teachers and students. In banking education the relationship between teacher and student is one of oppressor to oppressed. In emancipatory education, this opposition is expected to dissolve, transforming the student teacher relationship into one of love, where they work with each other, replacing the oppressive subject object relationship with one of co-subjects in praxis.

Such an equitable relationship frames the liberatory educator as one who works with oppressed people rather than one who comes from the outside to liberate on their behalf. The existence of this relationship is dependent on love and trust which are essential to dialogue and the initiation of a complex of dialectical relationships between critical thinking and dialogue, dialogue and reflection, reflection and action and 'I and thou' without which the trajectory to emancipation will fail. Freire describes the relationship between 
dialogue and critical thinking as being like that between reflection and action, in that they define each other. Critical thinking takes place if it generates dialogue and likewise true dialogue generates critical thinking. Dialogue cannot exist without critical thinking:

'which discerns an indivisible solidarity between the world and men, admitting of no dichotomy between them - thinking which perceives reality as process and transformation, rather than as a static entity thinking which does not separate itself from action, but constantly immerses itself in temporality without fear of the risks involved' (PO, 64-65).

I make no attempt to describe what is meant here except that this is where Freire relates the significance of 'the world' in emancipatory education, for dialogue and critical thinking are activities that must take place whilst co-intending upon concrete situations arising from the physical and social world. Here, Freire not only trusts people's relationships with each other, but also their relationships with the 'world' which they may reveal to each other without the unveilings of an educator.

But for the oppressed, praxis has broken down and there is a distorted perception of reality as it is. Freire argues that 'the world' must therefore be re-presented in symbolic form as educational materials geared precisely towards the lives and experiences of the oppressed students. If the content is too obvious, then education can degenerate into propaganda, sloganeering or knowledge deposits, but if it is too enigmatic it can turn into a puzzle or guessing game where the educator takes the role of revealing the answer (PO, 8687). Either way, these scenarios continue banking education as they block dialogue. To get around this problem the 'world' must be 'codified' encompassing the experiences and concerns of the students, so that it might instigate the dialogue that is integral to emancipation.

Here, Freire returns to the concept of people as historical beings, incorporating the historical philosophy of 
Hans Freyer which assumes that humanity creates not only material goods but also ideas, concepts and social institutions whilst they simultaneously create history and become 'historical-social beings'. It follows that the study of history or society can reveal ideas, values, concepts and hopes as well as oppressive situations. These are the themes of the current epoch and they both contain and are contained within limit-situations from which the limit-acts necessary to transform society may be detected (PO, 714). Following from this, Freire's educational practice describes a complicated process of producing a 'codified' world in the form of educational materials that encapsulate the reality of student's lives (PO, 75). Educator and students will co-intend upon the 'codified' world as if for the first time, investigating the themes through dialogue and enabling limit situations to be found. Educators can then pose these situations back to students as problems for them to solve. In so doing it is assumed that students can name the corresponding limit-acts and start to plan transformative actions; a 'conscientization' through dialogue that initiates praxis and drives forward history.

Freire argues that the teacher works alongside and not above the oppressed in the process of creating the codified materials, but there does seem to be a privileged role for the educators here. For example, sociologists and psychologists may be involved in validating that the materials are representative of students' lives (PO, p89). There are two issues here. Firstly, it places doubt over whether it is possible for an educator to maintain a relationship of co-subjects through dialogue with students, a problem already much discussed by critics of Freire's tradition ${ }^{17}$. Freire himself discusses the difficulty of the task in some detail (PO, 25, 50-59, 66-68) implying that well-meaning educators cannot make easy assumptions that they themselves are not enactors of oppression. Secondly, even if the teacher student relationship could be a non-dominatory relationship between co-subjects, there might no longer be a clear demarcation between the student and teacher, bringing into question whether an emancipatory situation continues to be an educational one rather than, say, one where people work co-operatively together on shared projects. This undermines Freire's argument that praxis is an inherently educational process, the problem being that this 
might leave emancipation with no role in education. Biesta describes the possibility of this situation as one where 'education dissolves into learning' ${ }^{18}$, where the teacher's role becomes that of a facilitator and the student to that of 'learner'. But these issues are circumvented by Rancière's theory of emancipatory education.

\section{Rancière's emancipatory education}

Freire's emancipatory trajectory from oppression is a humanising process of the reinstatement of people's innate character of being in praxis. Rancière's emancipation follows this model in that it is concerned with the reinstatement of the opinions about humanity which the theory makes and with the overcoming of knowledge transmission. However, Rancière's theory avoids the prospect of achieving a non-dominatory relationship between teacher and student by suggesting that it is a dominatory relationship of will against will that drives the emancipatory process. This means that the demarcation between student and teacher is maintained and remains recognisable as an educational relationship. Similarly Rancière's teacher is relinquished from any responsibility towards selecting appropriate educational materials because the educational process is independent of knowledge content and any gauging of people's existing awareness of it.

Three opinions are enacted in the emancipatory process; that all intelligences are equal; that man [sic] is a will served by an intelligence and that equality cannot be maintained in unions of men. This gives the liberatory educator two roles (IS 13-14) which are supported through the use of texts or visuals described as 'the book'. Firstly, to reinstate the equality of intelligence the emancipatory schoolmaster must be ignorant. This is not referring to the feigning of ignorance in order to help students to acquire knowledge, perhaps by a teacher asking questions of students whilst already knowing the answers. Neither is it a case of someone judging another person to be ignorant and then putting that person into the role of teacher. Rancière describes knowledge transmission as the entwining of two relations between student and teacher, 
that of will to will and that of intelligence to intelligence ${ }^{19}$. An ignorant schoolmaster is someone who teaches without transmitting knowledge, by dismantling the intelligence to intelligence relationship that creates the deficit between their own intellect and that of the student. This requires the ignorant schoolmaster to be ignorant of inequality by enacting the opinion that all people have equal intelligence. To do this, the teacher ignores the explanations that pervade from the social order and does not participate in any explicatory acts. Secondly, the teacher must demand that students pay attention to the power of their own intellect whilst acknowledging the intellect of others. The relationship of will against will is strengthened in order to weaken the relationship of intelligence to intelligence, where the will of the teacher drives the will of the student towards intellectual acts. This makes teaching for emancipation about verifying that students have paid attention; a new educational relationship described as a circle of power of the wills, where:

'The master is he who encloses an intelligence in an arbitrary circle from which it can only break out by becoming necessary to itself.' (IS, p15)

The consequence is that each student is propelled to follow their own circle of opinion forming and rely on their own will, in line with the third opinion that equality cannot be maintained in unions of people. Whilst Freire's emancipation is reliant on the maintenance of a relationships of co-subjects between teacher and student, it is the will of the educator that drives the emancipatory process making Rancière's educational relationship into one of domination - will against will. But this relationship can only be emancipatory if it is conducted under the auspices of the equality of intelligence. In this way, Rancière's emancipatory process removes the split between inferior and superior intelligences just as Freire's conscientization undoes the dichotomy between people and the world. Whilst Freire's theory raised questions about the status of dialogue and symbolic representations of 'the world' in the emancipatory process, for Rancière, there are questions about the status of the will and the status of the symbolic representations in 'the book'. 
The will is driven by the belief that all intelligences are equal, for this is what drives the need to understand and to be understood. Here the notion of the will is directly equated to reason, just as intelligence is synonymous with equality (IS, 73). To believe in the equality of intelligence means assuming that all people are capable of understanding each others' thoughts, emotions or opinions and to enact this belief requires tireless work. (IS, 9-10, 63-64). For example, a poet will expend enormous effort revising and correcting a poem because they work under the assumption that the readers will understand the results of this endeavour (IS, 68). Similarly, those who live within earshot of a musician will hear the same musical phrase repeated a thousand times. The argument is that if people are to enact their own intellectual power in the conduct of daily life, then this will require endlessly repetitive acts where everyday encounters are imitated, ordered, translated, reconsidered and compared so that opinions might be created and communicated to others, under the assumption that they too have the intelligence to understand them. (IS, 55). Whilst for Freire, such repetitive acts might be associated with banking education, for Rancière the acts of imitating, translating, taking apart and putting back together are enactments of equality providing they are undertaken in the belief that all others are equal in intelligence. Of course this repetitive activity is relentlessly boring, making the demanding of equality an act of the will, with the emancipatory teacher taking on the role of demander (IS, 55-6). There is a role for reflection here, understood as an unconditional attention to one's intellectual acts and the route that they follow (IS, 36-7), which contrasts with Freire's notion of reflection as a social contemplation of the social and physical world that cannot be separated from action.

What Rancière describes is a circular motion of emancipation where the will is driven by the belief that all people have equal intelligence, but where the enactment of this belief is driven by the will. The role of the teacher is to maintain and strengthen this motion. Rancière defines the guidance of intelligence by the will as attention (IS, 25), so more precisely, the role of the emancipatory teacher is to verify that the student has 
indeed attended to their will whilst they simultaneously acknowledge that all intelligences are equal. This is where symbolic representations of the 'world' become integral to the emancipatory process. Freire relies on 'codifications' that incorporate the concrete social and physical circumstances of students' lives so that they might become more fully conscious of them through the dialogue that re-instigates praxis and reconnects them to the 'world'. But for Rancière, people don't need reconnecting to the world because they are connected already. 'The book' is required to verify that students have paid attention and directed their intelligence and is described as:

'The thing in common, placed between two minds, is the gauge of that equality, and this in two ways. A material thing is first of all "the only bridge of communication between two minds". The bridge is a passage, but it is also distance maintained. The materiality of the book keeps two minds at an equal distance, whereas explication is the annihilation of one mind by another.' (IS, 32)

The student must engage with the text or picture (IS, 66), answering a three part question: what do you see, what do you think about it and what do you make of it? This allows the teacher to enforce the will of the student, encouraging the repetitive acts of translation, imitation and so on required for opinions to be formed. The symbols aren't veiled and then revealed incrementally through explanations so the student is no longer encouraged to believe that they understand less than the teacher or that say that they don't understand it (IS, 10). The purpose of emancipatory education is not to reveal knowledge about the world, but to reveal intelligence to itself, so any text or representation can be used (IS, 27-28).

Emancipatory teachers don't verify that students have found or understood, rather, they are verifying that students have searched and whether or not they have paid attention. Rancière asserts that the ignorant can easily tell when someone doesn't know what they are talking about, provided they are emancipated themselves (IS, 26), allowing the possibility for anyone, regardless of formal education or level of 
knowledge awareness to be an emancipatory teacher.

Though Rancière describes how any text can be used, to me the theory implies that the texts and symbols resulting from the work of the intellectually emancipated are not equivalent to the product of someone who is oppressed and stultified. The emancipated produce symbolic works that recognise the equality of all people (IS, 69-70). Such works need to be figured out, encouraging the exercising of the will and intellectual powers. In contrast, the product of stultified mind doesn't recognise the equality of intelligence in others. Such works explain and sloganise requiring the reader to listen and be commanded to for it is assumed that they might not be able to understand. In this way, the oppressed become responsible for enacting oppression, reminiscent of Freire's description of oppressors 'verbalism' and sloganeering, exemplified by the activities of revolutionaries, which results from theorising that is removed from practice. Rancière also relates how learned people find it very hard to stop explicating making their emancipatory teaching very reliant on 'the book' to maintain intellectual equality between themselves and students. On the other hand, the ignorant and uneducated find it much easier to be ignorant teachers and have less need for 'the book' for the purpose of preventing explication. However, as well as being ignorant, a master must also emancipate (IS, 14-15) by verifying that students have attended to their wills and the power of their own intellects. So, ignorant or learned, all teachers rely on 'the book' for this purpose and for which any representation can be used.

\section{Degrees of emancipation}

So far I have discussed how Freire and Rancière's descriptions of emancipation both rely on the enactment of assumptions they have made about human equality, where the character of the relationship between students and teachers drives an emancipatory process that is dependent upon symbolic representations such as texts or pictures. I shall also consider how both theories construct that people resist or avoid emancipation, require the teacher to be emancipated, link emancipated human activity to the physical and 
social world and finally, preclude the possibility for emancipatory education to be systemised within a formal education system.

Rancière describes how people tend to avoid having to deal with intellectual emancipation (IS, 16) and the change that it signifies. People will pretend that they can't understand and take on a public persona of humility, arguing that they are less intelligent than others (IS, 40) when actually they are just frightened of the consequences of their intellectual freedom (IS, 57). The 'fear of freedom' is also discussed by Freire (PO, 23-24, 99-100) as one where it is easier to conform to the oppressive social order than to enter risky relationships with potential comrades in emancipatory projects. Both theorists outline a tendency for the oppressed to become oppressors with Rancière describing the successful student who learns his lesson so that he might 'peer down on high from those he [sic] has surpassed' (IS, 22) in his role as lawyer, journalist or academic. Meanwhile Freire describes a culture where peasants strive to become landowners and where to be a 'real man' is to be oppressive (PO, 22). Also, there is also a tendency towards 'false generosity' (PO 21,36) where oppressors give charitably only to satisfy their guilt whilst situating the poor as passive receivers. This wider discussion by Freire suggests degrees of oppression and emancipation and complicated relationships within a class society which he discusses further in his later writings ${ }^{20}$. But in Pedagogy of the Oppressed the distinction between the oppressed and the emancipated seems clear cut. The teacher is unequivocally emancipated whilst 'the oppressed' are presented as a distinct group where it seems that I who read the theory cannot be oppressed myself. In contrast, Rancière presents fluctuating states of emancipation amongst different individuals at different times, where anyone in society, including the reader, can be oppressed, oppressor, emancipated or emancipator. As with Freire, Rancière's teacher must be emancipated the difference being that this cannot be a fixed state, for if a static intellectual state were reached then groups might come to hold to the same opinions and then intellectual freedom would be destroyed. This makes the emancipatory relationship reliant on movement; changes in the attention people give to their intellect where individual wills are in constant flux (IS, 78). 
The notion of praxis links Freire's theory to the social and physical world where there are endless possibilities for liberated people to think and act together to transform material reality. This also allows Freire to describe a material inequality understood in the sharpest terms as the starvation and disease that results from economic poverty. Freire's writing is in keeping with praxis as an attempt to theorise in response to such practical problems. Though Rancière's emancipation is referring to the intellectual freedom of individuals there are social and political dimensions. Belief in intellectual equality must be made public for emancipation to be effected, so students must communicate socially in some fashion (IS, $26)^{21}$. Also, there is still a link to the material world because people who are intellectually free develop opinions from their chance encounters in everyday life. Whilst Rancière theorises in response to a theoretical problem, constructing an immaterial inequality that originates in the belief in inequality ${ }^{22}$, 'individual emancipation carried to its logical extremes reconnects with shared concerns' ${ }^{23}$.

Like Freire, Rancière conveys a sense of history and of society in constant change. Over time, the number of people outside of the explicatory system has shrunk and humanity has been pedagogised with society likened to an enormous machine that promotes explanations (IS, 134). But whilst Freire points towards the prospect of an emancipated society, Rancière's movement of emancipation offers no such possibility. Whilst there is a past and a present, there is no projection to the future. Though Rancière doesn't account for class oppression like Freire does, the theory doesn't deny its existence and there is acknowledgement that the order of society does change (IS, 118) and that one social order might be infinitely preferable to another $^{24}$. But whilst the existence of a 'proletariat' is acknowledged, a class-based explanation of oppression cannot in itself offer emancipatory possibilities (IS, 137) ${ }^{25}$.

In Rancière's writing emancipation is not an end state for it can only be expressed in the present performed by individuals operating under the supposition that all intelligences are equal (IS, 46). Such expressions of 
equality can confront the logic of explication as it is enacted by society and effect political change, but the influence is sporadic ${ }^{26}$. Most of what would commonly be described as political activity produces change that extends and replicates the oppressive social order, including many actions of the groups that aspire to notions of solidarity ${ }^{27}$. But enactments of intellectual emancipation may effect a reconfiguration of the existing explanatory system so that it incorporates an inscription of equality. This political change may be fleeting and occurs only rarely. But Rancière doesn't downplay its significance, for 'at the moment when society is threatened to be shattered by its own madness, reason performs a saving social action by exerting the totality of its own power, that of the recognised equality of intellectual beings.' (IS, 97)

So, for opposing reasons, neither Freire nor Rancière's emancipatory education can be systemised. Likewise, for both, emancipatory education is a never ending process. For Freire, emancipatory education can only take place as discrete projects within an oppressive society and systemisation is only possible after a social revolution when the oppressor class has been defeated. Emancipatory education itself is a revolutionary project where educators are revolutionaries. For a revolution to be successful praxis must be sustained as an educational process and in this sense there is never an end point for an emancipatory education. With Rancière, social emancipation is impossible because the very existence of society and its institutions relies upon the union of intellects, making all societies inherently oppressive. But emancipatory education continues without cease, driven by individual wills that affect the social order in the manner of a fluctuating and sporadic flame which hasn't yet been extinguished.

\section{Summary and conclusion}

Through reconstructing the two theories in parallel I have shown that the assumptions that Freire and Rancière make about human beings have consequences for how they each conceptualise oppression, emancipation and associated educational practices. Freire describes how all people are equally predisposed to live in praxis; a dynamic social relationship between reflection and action that is understood as a truth 
assumption about the innate character of human beings. Rancière holds the opinion that all people have equal intelligence and that a person's intelligence is directed by their will. But an opinion is just an opinion. Unlike Freire, Rancière reminds us that the assumptions we make about people are not truths, demonstrating the importance of people creating their own opinions and how these might connect with shared concerns. Taking the two theories together, we are encouraged to consider how the assumptions that we make about humanity, whether we consider them to be truths or matters of opinion, have repercussions for how we understand and practice education. What's more, we cannot assume that educational activity is neutral for the repercussions may be oppressive.

I have shown how both Freire and Rancière adopt a similar model in order to conceptualise oppression and emancipation. They each take the assumptions that they make about people and use them to produce a definition of equality. Oppression is then defined an educational activity that suppresses or disrupts the enactment of the assumptions that they have made about humanity. Freire and Rancière both conceptualise this process of oppression as a form of knowledge transmission that encourages students to be dependent upon teachers. For Freire, oppression is described by the banking education model, where teachers deposit knowledge, channelling it directly into students' consciousness. This activity blocks dialogue and in so doing disrupts praxis, enforcing a dichotomy between people and the world so that they cannot intend upon reality through their own choices and decisions. The oppressed, as students, are no longer able to reflect and act together. Instead they are dependent on oppressors, as teachers, for their knowledge of the world. For Rancière, the transmission of knowledge from teacher to student is considered as the entwining of two relations, that of intelligence to intelligence and will to will. The intelligence to intelligence relationship replicates inequality through acts of explication by the teacher that weaken the will of the student and the attention they pay to their own intellect. Here a dichotomy is created between ignorant and knowing minds. This encourages the belief that people have different intelligences, weakening individual 
wills and the activity by which opinions are formed, creating a dependency between oppressed and oppressor where students believe that they must rely on a teacher in order to understand.

For both theorists, the central concern of emancipatory education is to overcome knowledge transmission and the dependency that it creates between student and teacher which replicates inequality. With Freire this requires teachers to initiate dialogue in a relationship of love that re-instigates praxis, removing the dichotomy between people and the world. For Rancière an emancipatory education must reinstate the equality of intelligence, where the will of the teacher demands students to direct their own intelligence whilst acknowledging the intelligence of others. Here the will to will relationship is strengthened in order to drive the dismantling of the relationship of intelligence to intelligence, removing the dichotomy between the ignorant and the knowing.

I have also demonstrated that these two understandings of emancipatory education have opposing consequences for educational practices. But for both Freire and Rancière emancipation is dependent on two central features. Firstly on the character of the relationship between teachers and students and secondly on the necessity of a relationship between these people and educational materials that they use such as texts or other artefacts. In the case of Freire, the teacher and students must be co-subjects, a relationship of love in praxis. Here texts, pictures and so on are used to prevent knowledge transmission as the teacher and students might co-intend on these through the practices of dialogue and critical thinking that drive praxis. But these 'codifications' must incorporate representations of the lives and concerns of students so that there is no need for a teacher to interpret them on their behalf and in so doing resort to banking education. In the case of Rancière, emancipatory education demands an unequal relationship between teachers and students, as it is the will of the teacher that drives the emancipatory movement toward equality of intelligence, insisting that the student pays attention to their own intellect. To do this, the teacher utilises what Rancière describes as 'the book'; a text or picture that mediates between the 
intelligence of the teacher and that of the student, preventing the teacher from explicating and discouraging the student from claiming that they don't understand. Here the purpose is not for teachers to reveal knowledge about the world, but to reveal intelligence to itself, so the content is irrelevant to emancipation and any text or picture could be used.

I have raised four aspects of Freire's theory that have been criticised historically and which Rancière's theory seems to avoid. Firstly, that Freire makes truth assumptions about humanity in order to describe education and oppression, which has been criticised for being both impossible and undesirable. Rancière avoids this by presenting assumptions as being just opinions, where inequality is itself just an opinion. Secondly, Freire relies upon a notion of oppression as false consciousness, where people might not understand the reality of their own oppression and with the associated problem of how to overcome this without resorting to knowledge transmission. Rancière's theory doesn't rely on understandings of humans as conscious beings and so avoids this difficulty. Thirdly, Freire conceptualises the necessity of a relationship where teachers and students as co-subjects, which has been criticised on the basis of its impossibility. Also, that if it were achieved, there might be no demarcation between teacher and student perhaps leaving emancipation with no role in education. Again, Rancière avoids this, conceptualising an emancipation that is reliant upon a relationship of will against will between teacher and student, preserving an educational relationship. Finally, though Freire acknowledges the complexity of oppressive relationships, there has been criticism that the theory struggles to adequately describe this. Here Rancière makes the very possibility of emancipation reliant upon fluctuating states of oppression and emancipation. However unlike Freire, Rancière offers no prospect of a social emancipation that might overcome material inequality such as starvation and preventable disease. But on the other hand the emancipation that Rancière does describe cannot be deferred to a post-revolutionary future that is forever over the horizon. Emancipation can only be enacted in the present. 
But the aim of this essay was not to compare the efficacy of Rancière's theory over that of Freire. Rancière's theory is just an opinion and as such it cannot be the last word on the subject of emancipatory education. For me, the importance of Rancière's theory is that it continues to take responsibility for the issues and concerns that Freire raised. In this essay I have argued that both Freire and Rancière are fundamentally concerned with the possibility of distinguishing between education that might socialise people into an inherently oppressive society and education with emancipation as a purpose and which might create alternatives. Their differing conceptualisations of oppression share the same concerns; that the consequences of education are never neutral and that educational practices that are based upon knowledge transmission cannot be emancipatory. Both Freire and Rancière acknowledge this as particularly problematic given the proliferation of organisations, be they political parties, revolutionary organisations, charitable foundations or universities, which aim to reduce societal inequality by passing down knowledge to people under the belief that they are asserting against oppression. In this sense, I would argue that they both question the educational practices associated with popular understandings amongst critical educators who act under the belief that revealing knowledge about how power operates might lead to emancipation.

In their conceptualisations of emancipatory education both Freire and Rancière emphasise the processes by which knowledge is created, how these might connect with shared concerns, and the importance of all people engaging in such activity. Rancière takes this further than Freire by drawing our attention to the consequences of making truth assumptions about the nature of humanity. For me, taking the two theories together encourages the discussion of all the educational issues I have mentioned here and might even suggest further possibilities. Here I have argued that Rancière and Freire share a similar model in the construction of their theories, demarcated by the assumptions that they make about human beings. But need any assumptions be made about people to discuss the possibility of an emancipatory education? 
A concern both theorists share is how understandings of emancipation that are reliant upon knowledge transmission create a hierarchical dependency between those who consider themselves to be emancipators (as teachers) and oppressed people (as students), where students must rely upon external judgements about whether their emancipation is necessary or in occurrence. Both Freire and Rancière set out to remove this dependency. With Freire, emancipation is natural and innate to humanity whilst for Rancière, Jacotot's emancipation is the oldest method practiced throughout history (IS, 16). For both, the chances for emancipatory practices are undermined by oppressive processes in society, but none the less they both speculate that emancipation takes place regardless of outside intervention. However, Freire also posits that emancipation need not be left totally to chance and that there is a role for education (PO, 48-49). Whilst Rancière is less emphatic on this his writing emphasises the significance of all intellects, making the possibility of an emancipatory education into a question that by definition should not be ignored and which can only be addressed in the present.

(To cite: Galloway, Sarah, (in press), 'Reconsidering emancipatory education: Staging a conversation between Paulo Freire and Jacques Rancière', Educational Theory)

\section{Acknowledgements}

I would like to thank Gert Biesta for reading and discussing this essay and everyone at the Laboratory for Educational Theory, Stirling University for supporting my work.

\footnotetext{
${ }^{1}$ Paulo Freire, Pedagogy of the Oppressed. (Harmondsworth:Penguin Books, 1972). This work will be cited in the text as PO for all subsequent references

${ }^{2}$ Eg Freire, Paulo, Education for Critical Consciousness, (London:Sheed and Ward Ltd, 1974), Freire, Paulo \& Macedo, Donaldo, Literacy: Reading the Word and Reading the World, (Massachusetts: Bergin \& Garvey Publishers, Inc, 1987), , Freire, Paulo and Shor, Ira, A Pedagogy for Liberation: dialogues on
} 
transforming education,(Basingstoke: Macmillan Education Ltd, 1987). However, I refer to Pedagogy of the Oppressed as the main text to inform this essay

${ }^{3}$ Jacques Rancière, The Ignorant Schoolmaster: Five Lessons in Intellectual Emancipation. (Stanford California: Stanford University Press, 1991). This work will be cited in the text as IS for all subsequent references

${ }^{4}$ Eg Charles Bingham and Gert Biesta, J.J. eds. with Jacques Rancière, Jacques Rancière: Education, truth, emancipation. (London/New York: Continuum, 2010).; Tanke, J.J., “Why Rancière Now?”, Journal of Aesthetic Education 44, no. 2 (2010): 1-10. Caroline Pelletier, "Emancipation, equality and education: Rancière's critique of Bourdieu and the question of performativity", Discourse: Studies in the Cultural Politics of Education 30, no. 2 (2009): 137-150.

${ }^{5}$ Gert Biesta, "Towards a new 'logic' of emancipation:Foucault and Rancière" in Philosophy of Education 2008, ed. Ron Glass (Urbana, Illinois: Philosophy of Education Society 2009);

Gert Biesta, J.J. “A new 'logic' of emancipation: The methodology of Jacques Rancière”, Educational Theory 60, no. 1 (2010): 39-59, http://onlinelibrary.wiley.com/doi/10.1111/j.1741-5446.2009.00345.x/full; Bingham and Biesta, Jacques Rancière, 25-4832-33, 38-40)

${ }^{6}$ To date there has been no direct comparison made between the theories of Paulo Freire and Jacques Rancière, though Lewis does use Rancière to discuss Freire in the context of the aesthetics of teaching and Bingham scrutinises Rancière's methodology in reference to Freire as well as the figure of the child in Freire's pedagogy (Lewis, Tyson “Education in the Realm of the Senses: Understanding Paulo Freire's Aesthetic Unconscious through Jacques Rancière", Journal of Philosophy of Education 43, no. 2 (2009): 285-299,

Lewis, Tyson “Paulo Freire’s Last Laugh: Rethinking critical pedagogy’s funny bone through Jacques Rancière", Educational Philosophy and Theory 42, no. 5-6 (2010): 635-647, Charles Bingham, "Under the Name of Method: On Jacques Rancière's Presumptive Tautology”, Journal of Philosophy of Education 4, 
no. 3 (2009): 405-420)

${ }^{7}$ For background to the question of the purpose of including education for socialisation and education for subjectification see Biesta

Biesta, G, 'Good education in an age of measurement: on the need to reconnect with the question of purpose in education', Educational Assessment, Evaluation and Accountability 21, no1(2008):33-46, DOI: $10.1007 /$ s11092-008-9064-9

${ }^{8}$ See Gert Biesta, J.J., Beyond Learning: Democratic Education for a Human Future (Colorado: Paradigm Publishers, 2006)

${ }^{9}$ Freire restates this argument in his dialogue with Ira Shor on 'empowerment as a social act' in Shor, 'What is critical literacy?', Journal for Pedagogy, Pluralism and Practice, (1997), http://www.lesley.edu/journals/jppp/4/shor.html (last accessed March 2011)

${ }^{10}$ Eg Stromquist, N. P., Literacy for citizenship: Gender and grassroots dynamics in Brazil. (Albany: State University of New York Press, 1997); Kathleen Weiler, "Freire and a Feminist Pedagogy of Difference" in Politics of Liberation: Paths From Freire, eds. Peter McLaren and Peter Lankshear (London and New York: Routledge, 1994); Carmen Luke, "Feminist Politics and Radical Pedagogy" in Feminisms and Critical Pedagogy, eds. Carmen Luke and Jennifer Gore (New York:Routledge, 1992);

Patti Lather, "Critical Pedagogy and its complicities: A praxis of stuck places”, Educational Theory 48, no. 4 (1998): 487-497, http://onlinelibrary.wiley.com/doi/10.1111/j.1741-5446.1998.00487.x/full

${ }^{11}$ See Gert Biesta, J.J., Beyond Learning: Democratic Education for a Human Future: 5

${ }^{12}$ See Biesta, “A new 'logic' of emancipation”, 46-47 
${ }^{13}$ For example, Jacques Rancière, On The Shores of Politics, trans Liz Heron (London:Verso, 1995), 4552, 63-92, or for a summary of Rancière's conceptualisation see Biesta, “A new 'logic' of emancipation”, $46-56$

${ }^{14}$ The English translations of both Freire and Rancière cited here use the terms 'man' and 'men' to refer to all people. I don't address gender in this essay and I have no wish to amend this language on behalf of the writers and in so doing conceal it from the reader. I prefer to draw your attention to it by retaining it in the text for your own consideration.

${ }^{15}$ See Biesta, “A new 'logic' of emancipation”, 51-52

${ }^{16}$ This is also discussed in some detail in Bingham and Biesta, Jacques Rancière

${ }^{17}$ Giroux (Giroux, Henry, A, "Lessons to Be Learned From Paulo Freire as Education Is Being Taken Over by the Mega Rich,", t r u t h o u t | Op-Ed, (Tuesday, 23 November 2010) http://www.truthout.org/lessons-be-learned-from-paulo-freire-education-is-being-taken-over-mega-rich65363 accessed, March 2011)

discusses how Freire's later writing acknowledges the complexity of relationships between teachers and students. But the possibility of linking dialogue to non-dominatory between teachers and students has been criticised more fundamentally, for example by Jackson in the context of children's education and social justice. Also by Coben (Coben, D. Paulo Freire's Legacy for Adults Learning Mathematics. Adults Learning Mathematics Conference (4th, Limerick, Ireland (1997)), retrieved from http://www.eric.ed.gov/PDFS/ED436428.pdf)

, when discussing Freire's legacy for mathematics education argues that Freire has an inadequate concept of power and how it is reproduced. In similar vein, Taylor (Taylor, The Texts of Paulo Freire,(Buckingham:Open University Press), 1993, 59) refers to Freire's over simplistic understandings of society and the relationships between individuals and the institutions within it. Gur-Ze'ev (Gur-Ze'ev, Ilan, (1998), “Toward a Nonrepressive Critical Pedagogy”, Educational Theory 48, no 4 (1998): 463-486) 
questions Freire's linkage of the idea of love as the essence of dialogue to the attainment of a positive utopia, speculating the possibility of violent consequences. Also by various writers from a feminist/poststructuralist perspective Ellsworth, Elizabeth, "Why Doesn't This Feel Empowering?", Harvard Educational Review 59, no 3 (1989): 297-324; Luke, Carmen, "Feminist Politics and Radical Pedagogy" in Feminisms and Critical Pedagogy, Eds. Luke, Carmen and Gore, Jennifer (New York:Routledge, 1992); Ormer, Mimi. "Interrupting the Calls for Student Voice in "Liberatory" Education: A Feminist Poststructural Perspective" in Feminisms and Critical Pedagogy, Eds. Luke, Carmen and Gore, Jennifer (New York:Routledge, 1992)

${ }^{18}$ Gert Biesta, J.J. "Learner, student, speaker. Why it matters how we call those we teach", Educational Philosophy and Theory 60, no. 1 (2010b): 39-59; http://onlinelibrary.wiley.com/doi/10.1111/j.14695812.2010.00684.x/full, 544

Taylor also describes how Freire's later preference to refer to 'cultural action' rather then 'education', as found in the title of his Harvard papers "Cultural Action for Freedom” (See Taylor, 63)

19 Jacques Rancière, “On Ignorant Schoolmasters” in Jacques Ranciere:Education, Truth, Emancipation eds. Charles Bingham and Gert Biesta (London:Continuum, 2010), 1-5

${ }^{20}$ For example see Freire, Pedagogy of Hope, New York: Continuum (2004) or Peters, "Pedagogy, Neoliberalism and Postmodernity: Reflections on Freire's Later Work", Educational Philosophy and Theory 35, no. 4 (2003): 451-465

${ }^{21}$ See also Biesta, J.J. “Learner, student, speaker” and Rancière, On the Shores of Politics, 51

${ }^{22}$ Perhaps this essay does something similar by considering only the theoretical aspect of Freire's work.

${ }^{23}$ Rancière, On the Shores of Politics, 51

${ }^{24}$ Bingham and Biesta, Jacques Rancière, 37.

${ }^{25}$ Bingham and Biesta, Jacques Rancière, 32-38.

${ }^{26}$ Bingham and Biesta, Jacques Rancière, 37. 
${ }^{27}$ Ibid. Rancière describes the explicatory social order as the 'police order' and 'politics' only refers to the emancipatory expressions that confront its logic. All other activity commonly considered to be political eg parliament, lobbying, industrial solidarity or revolutionary organisation is considered as 'policing' rather than 'politics' (Bingham and Biesta, Jacques Rancière, 32-38, Biesta, “Learner, Student, Speaker”, 546547) 